\title{
PENGARUH PEMBELAJARAN DARING TERHADAP MINAT BELAJAR SISWA KELAS VII MTS YASRIB BATU-BATU PADA MASA COVID-19
}

\author{
Hidayatullah $^{1}$, Gusniwati, S. Si. M. Pd ${ }^{2}$, Dr. Buhaerah, M. Pd \\ ${ }^{1}$ Program Studi Tadris Matematika Fakultas Tarbiyah IAIN PAREPARE \\ ${ }^{2}$ Program Studi Tadris Matematika Fakultas Tarbiyah IAIN PAREPARE \\ ${ }^{3}$ Program Studi Tadris Matematika Fakultas Tarbiyah IAIN PAREPARE \\ 'hidayatullah@iainpare.ac.id \\ ${ }^{2}$ gusniwati@iainpare.ac.id \\ 3buhaerahstain@gmail.com
}

\begin{abstract}
Abstrak: Artikel ini menggunakan penelitian kualitatif. Artikel penelitian kualitatif ini bersifat deskriptif yang menggunakan analisis data kualitatif sehingga menjadi paparan data mudah dimengerti. Pembelajaran pada sekolah menengah pertama atau madrasah tsanawiyah (MTs) dalam penelitian ini menggunakan pembelajaran secara daring atau biasa disebut dengan pembelajaran jarak jauh (dari rumah) dengan bimbingan orang tua dan guru di sekolah. Siswa melakukan pembelajaran daring dan berinteraksi dengan guru menggunakan aplikasi Whatsapp Group. Penelitian ini bertujuan untuk mengetahui pengaruh pembelajaran daring terhadap minat belajar siswa pada masa COVID-19. Responden yang diambil adalah siswa dan guru di MTs Yasrib Batu-batu. Hasil penelitian ini menunjukkan bahwa pembelajaran daring pada masa pandemi COVID-19 sangat berpengaruh terhadap minat belajar siswa, siswa merasa bosan karena tidak bertemu dengan teman dan gurunya secara langsung.
\end{abstract}

Katakunci: pembelajaran daring; minat belajar; COVID-19.

\begin{abstract}
This article uses qualitative research. This qualitative research article is descriptive in nature which uses qualitative data analysis so that it becomes easy to understand data exposure. Learning at junior high schools or madrasah tsanawiyah (MTs) in this study uses online learning or what is commonly called distance learning (from home) with the guidance of parents and teachers at school. Students do online learning and interact with teachers using the Whatsapp Group application. This study aims to determine the effect of online learning on student interest in learning during the COVID-19 period. Respondents taken were students and teachers at MTs Yasrib Batu-batu. The results of this study indicate that online learning during the COVID-19 pandemic greatly affects students' interest in learning, students feel bored because they don't meet their friends and teachers directly.
\end{abstract}

Keywords: online learning; interest to learn; COVID-19. 


\section{Pendahuluan}

Coronavirus adalah keluarga besar virus yang menyebabkan penyakit mulai dari gejala ringan sampai berat. Coronavirus Disease 2019 (COVID-19) adalah penyakit jenis baru yang belum pernah diidentifikasi sebelumnya pada manusia. Pada 31 Desember 2019, WHO China Country Office melaporkan kasus pneumonia yang tidak diketahui etiologinya di Kota Wuhan, Provinsi Hubei, Cina. Pada tanggal 7 Januari 2020, Cina mengidentifikasi pneumonia yang tidak diketahui etiologinya tersebut sebagai jenis baru coronavirus (coronavirus disease, COVID-19). Pada tanggal 30 Januari 2020 WHO telah menetapkan sebagai Kedaruratan Kesehatan Masyarakat Yang Meresahkan Dunia/Public Health Emergency of International Concern (KKMMD/PHEIC). Penambahan jumlah kasus COVID-19 berlangsung cukup cepat dan sudah terjadi penyebaran antar Negara (Isbaniah, 2020). Per Rabu (4/11/2020) pukul 20:25 WIB, tercatat total kasus Covid-19 terkonfirmasi di seluruh dunia ada 47.555.607 kasus (Tiarasari, 2020). Pandemi COVID-19 merupakan musibah yang memilukan bagi seluruh penduduk bumi. Seluruh kehidupan manusia di bumi terganggu, tanpa kecuali pendidikan. Banyak negara memutuskan menutup sekolah, perguruan tinggi maupun universitas, termasuk negara Indonesia (Syah, 2020).

Adanya virus covid-19 pada tahun 2020 memberikan dampak yang luar biasa hampir pada semua bidang, salah satunya pada bidang pendidikan. Dengan adanya virus covid-19 ini membuat proses pembelajaran menjadi berubah dari yang tatap muka menjadi pembelajaran jarak jauh, tetapi dalam keadaan seperti ini pun guru masih tetap harus melaksanakan kewajibanya sebagai pengajar, dimana guru harus memastikan siswa dapat memperoleh informasi/ilmu pengetahuan untuk diberikan kepada siswa (Aulia, 2020).

Di Indonesia, pembelajaran jarak jauh atau daring ini dimulai pada tanggal 16 maret 2020, dimana anak mulai belajar dari rumahnya masing-masing tanpa perlu pergi ke sekolah. Berbicara mengenai pembelajaran jarak jauh atau daring maka pentingnya penguasaan ilmu teknologi bagi seorang guru agar pembelajaran jarak jauh tetap berjalan dengan efektif di saat pandemi seperti ini. Kelangsungan pendidikan selama pandemi akan tergantung pada berbagai faktor, seperti tingkat persiapan sekolah, kesiapan orang tua/keluarga, serta kesiapan guru. Pertimbangan harus diberikan pada kebutuhan semua siswa untuk terus memberikan pendidikan selama berlangsungnya pandemi. Selain menggunakan hardcopy dari bahan ajar, seperti buku, buku kerja, dan sekolah dapat menggunakan berbagai solusi berbasis teknologi untuk meningkatkan kemungkinan siswa dapat melanjutkan aktivitas pembelajaran mereka.

Konsekuensi dari penutupan Lembaga Pendidikan secara fisik dan mengganti dengan belajar di/dari rumah sebagaimana kebijakan pemerintah adalah adanya perubahan sistem belajar mengajar. Pengelola sekolah, siswa, orangtua, dan tentu saja guru harus bermigrasi ke sistem pembelajaran digital atau online, yang lebih dikenal dengan istilah e-learning atau dikenal dengan istilah pembelajaran dalam jaringan atau "pembelajaran daring" di Indonesia. Negara Indonesia juga relatif tidak berbeda dengan negara lain. Meskipun menyadari bahwa ada disparitas terhadap akses teknologi pembelajaran dan beragamnya latar belakang orang tua, Kementerian Pendidikan dan Kebudayaan Republik Indonesia dengan tegas memberlakukan kebijakan 
pembelajaran daring (Wahyono \& Husamah, 2020).

Pembelajaran daring pada dasarnya merupakan pembelajaran yang dilakukan secara virtual memalui aplikasi virtual yang tersedia. Walaupun demikian, pembelajaran daring harus tetap memperhatikan kompetensi yang akan diajarkan. Pembelajaran daring bukan sekedar materi yang dipindah melalui media internet, bukan juga sekedar tugas dan soal-soal yang dikirimkan melalui aplikasi sosial media. Pembelajaran daring harus direncanakan, dilaksanakan, serta dievaluasi sama halnya dengan pembelajaran yang terjadi di kelas. Siswa melakukan pembelajaran daring dan berinteraksi dengan guru menggunakan beberapa aplikasi yang di pakai seperti Google Classroom, Zoom, Google Meet, Whatsapp Group dan lain sebagainya. Pembelajaran ini merupakan inovasi pendidikan untuk menjawab tantangan akan ketersediaan sumber belajar yang variatif.

Seluruh jenjang pendidikan dari Sekolah Dasar/Ibtidaiyah sampai Perguruan Tinggi (Universitas) baik yang berada di bawah Kementerian Pendidikan dan Kebudayaan RI maupun yang berada di bawah Kementerian Agama RI semuanya memperoleh dampak negatif karena pelajar, siswa dan mahasiswa "dipaksa" belajar dari rumah karena pembelajaran tatap muka ditiadakan untuk mencegah penularan COVID-19. Padahal tidak semua pelajar, siswa dan mahasiswa terbiasa belajar melalui online. Apalagi guru dan dosen masih banyak belum mahir mengajar dengan menggunakan teknologi internet atau media sosial terutama di berbagai daerah (Purwanto et al., 2020).

Pembelajaran online juga sangat mempermudah pelajar dalam mengikuti pembelajaran daring, seperti yang sudah diterapkan sekarang ini ketika banyak sekolah yang diliburkan karena untuk mencegah penyebaran COVID-19 dan sudah digantikan dengan pembelajaran yang diterapkan di rumah dengan menggunakan pembelajaran daring (online). Pembelajaran daring mempuyai banyak manfaat, yang pertama dapat membangun komunikasi dan diskusi yang sangat efisien antara guru dengan murid, kedua siswa saling berinteraksi dan berdiskusi antara siswa yang satu dengan yang lainnya tanpa melalui guru, ketiga dapat memudahkan interaksi antara siswa guru, dengan orang tua, keempat sarana yang tepat untuk ujian maupun kuis, kelima guru dapat dengan mudah memberikan materi kepada siswa berupa gambar dan vidio selain itu murid juga dapat mengunduh bahan ajar tersebut, keenam dapat memudahkan guru membuat soal dimana saja dan kapan saja (Meidawati \& Veteran Bangun Nusantara Sukoharjo, 2019).

Sistem pembelajaran yang dilaksanakan melalui komputer atau laptop yang terhubung dengan koneksi jaringan internet. Guru juga dapat melakukan pembelajaran bersama di waktu yang sama menggunakan grup di media sosial seperti media Whatsapp (WA), Telegram, aplikasi Zoom ataupun media lainnya sebagai media pembelajaran. Dengan itu guru dapat memastikan siswa mengikuti pembelajaran dalam waktu yang bersamaan, meskipun di tempat yang berbeda.

Minat belajar adalah salah satu faktor yang sangat penting untuk keberhasilan belajar yang dimiliki siswa, minat muncul dari dalam diri siswa itu sendiri. Faktor dari luar minat belajar yaitu bagaimana cara guru tersebut mengajar. Peran guru sangat penting untuk menumbuhkan minat belajar siswa salah satu dengan cara mengajar yang menyenangkan, memberikan motivasi yang membangun (Riamin, 2016). 
Minat belajar merupakan sikap ketaatan dalam kegiatan proses belajar, baik yang menyangkut perencanaan jadwal belajar yang dimilikinya maupun inisiatif dirinya sendiri melakukan usaha tersebut dengan bersungguh-sungguh dalam belajar (Andriani \& Rasto, 2019).

Minat belajar merupakan suatu rasa untuk menyukai atau tertarik pada suatu hal dan aktivitas belajar tanpa ada yang menyuruh untuk belajar (Ricardo \& Meilani, 2017). Minat belajar juga merupakan faktor pendorong untuk siswa dalam belajar yang didasari atas ketertarikan atau juga rasa senang keinginan siswa itu untuk belajar.

Minat belajar juga mempunyai indikator-indikator di dalamnya yaitu adanya perasaan tertarik dan juga senang untuk belajar, adanya partisipasi yang aktif, adanya kecenderungan untuk memperhatikan dan daya konsentrasi yang besar, memiliki perasaan positif dan kemauan belajar yang terus meningkat, adanya kenyamanan pada saat belajar, dan dimilikinya kapasitas dalam membuat keputusan berkaitan dengan proses belajar yang dijalaninya.

Minat seseorang terhadap pelajaran dan proses pembelajaran tidak muncul dengan sendirinya akan tetapi banyak faktor yang dapat mempengaruhi munculnya minat. Salah satu faktor yang dapat membangkitkan dan merangsang minat adalah faktor bahan pelajaran yang akan diajarkan kepada siswa. Bahan pembelajaran yang menarik minat siswa, akan sering dipelajari oleh siswa yang bersangkutan, dan sebaliknya bahan pembelajaran yang tidak menarik minat siswa tentu akan dikesampingkan oleh siswa. Oleh karena itu bila bahan pelajaran yang dipelajari tidak sesuai dengan minat siswa, maka siswa tidak akan belajar dengan sebaik-baiknya, karena tidak ada daya tarik baginya (Mulyana, 2020).
Guru juga dituntut untuk bisa memaksimalkan minat atau bakat yang telah ada pada diri siswa dan menemukan yang baru. Hal tersebut bisa dilakukan dengan cara memberikan wawasan tentang kegunaan atau manfaat dari sebuah pelajaran. Misalnya menjelaskan manfaat belajar sejarah, matematika atau sosiologi di kehidupan sehari-hari. Usahakan menjelaskan manfaat yang tidak jauh dengan kehidupan sehari-hari siswa (Adhi, 2020).

Minat belajar adalah salah satu faktor yang sangat penting untuk keberhasilan belajar yang dimiliki siswa, minat muncul dari dalam diri siswa itu sendiri. Faktor dari luar minat belajar yaitu bagaimana cara guru tersebut mengajar.

Setelah melakukan kajian literasi jurnal-jurnal, sehingga bisa diadakannya penelitian mengenai bagaimana pengaruh pembelajaran daring terhadap minat belajar siswa MTs Yasrib Batu-batu pada masa COVID-19 untuk menjawab bagaimana pengaruh pembelajaran daring terhadap minat belajar siswa tersebut dari sudut pandang guru dan siswa yang ada di MTs Yasrib Batu-batu. Karena dengan keadaan yang baru ini, pelaksanaan pembelajaran tidak akan sama dengan pembelajaran yang biasanya dilakukan di sekolah.

Penelitian ini fokus pada pengaruh pembelajaran daring terhadap minat belajar siswa yang dilakukan oleh pihak sekolah. Penelitian ini bertujuan untuk mengetahui pengaruh pembelajaran daring terhadap minat belajar siswa pada masa COVID-19 saat ini terjadi.

\section{Metodologi Penelitian}

Artikel ini menggunakan metode penelitian kualitatif. Penelitian kualitatif merupakan penelitian yang bersifat deskriptif dan cenderung menggunakan analisis. Karakteristik penelitian 
kualitatif yaitu melakukan penelitian dalam kondisi yang alamiah, langsung ke sumber data, peneliti menjadi instrumen kunci, menyajikan data-data dalam bentuk kata-kata atau gambar dan tidak menekankan angka-angka, melakukan analisis data. Metode penelitian kualitatif ini tidak dimanipulasi oleh peneliti, analisis data berdasarkan fakta-fakta yang ditemukan di lapangan (Sugiyono, 2015).

Sumber data yang diambil oleh peneliti yaitu hasil wawancara peneliti dengan guru yang ada di Sekolah. Data yang diperoleh dari guru berupa opini dari hasil wawancara dengan peneliti. Setelah itu data akan dikumpulkan sesuai dengan apa yang diinginkan oleh peneliti. Selain sumber data hasil wawancara dari guru, peneliti, bisa juga hasil dokumentasi berbagai literatur yaitu berupa jurnal, artikel ataupun yang berkaitan dengan penelitian.

Subjek penelitian ini adalah siswa MTs yasrib Batu-batu yang mengikuti pembelajaran selama masa pandemi COVID-19 ini dan guru. Total subyek penelitian yaitu 13 responden, 1 orang guru yang ada di Sekolah, 2 orang tua yang ada di sekitar rumah, tidak semua orang tua yang mau diwawancarai jadi hanya 2 orang saja yang bisa diwawancarai, 8 orang siswa SD/MI di sekitar rumah. Pengumpulan data yang dilakukan melalui Google Form.

Untuk memerika keabsahan data penelitian, peneliti menggunakan teknik referensi yang diperoleh selama penelitian seperti jurnal penelitian, jawaban responden, untuk menguji dan mengoreksi hasil penelitian yang sudah dilakukan.

\section{Hasil dan Pembahasan}

Pandemi COVID-19 merupakan musibah yang memilukan bagi seluruh penduduk bumi. Seluruh kehidupan manusia di bumi terganggu, tanpa kecuali pendidikan. Banyak negara memutuskan menutup sekolah, perguruan tinggi maupun universitas, termasuk negara Indonesia. Coronavirus atau virus corona merupakan keluarga besar virus yang menyebabkan infeksi saluran pernapasan atas ringan hingga sedang, seperti penyakit flu. Banyak orang terinfeksi virus ini, setidaknya satu kali dalam hidupnya (Fadli, 2020).

Pada masa pandemi COVID-19 ini, siswa yang dulunya belajar secara tatap muka atau luring dialihkan dengan belajar secara daring menggunakan media online. Meskipun belajar secara daring di rumah siswa tetap belajar sepert di sekolah, yang membedakan hanya pada media yang digunakan, seperti menggunakan via Zoom, Google Meet atau teleconference lainnya. Pada saat pembelajaran dari rumah siswa juga diberikan materi seperti belajar di sekolah yang berbeda hanya jam belajarnya saja untuk yang lainnya masih sama.

Pembelajaran daring dapat dijadikan solusi pembelajaran jarak jauh ketika terjadi bencana alam. Seperti yang terjadi saat ini ketika pemerintah menetapkan kebijakan social distancing. Social distancing diterapkan oleh pemerintah dalam rangka membatasi interaksi manusia dan menghindarkan masyarakat dari kerumunan agar terhindar dari penyebaran virus COVID19 (Syarifudin, 2020,p.31).

Pemerintah menganjurkan seluruh siswa untuk belajar di rumah di bawah pengawasan orang tua. Pertama, anak tetap belajar, dengan menggunakan metode pembelajaran yang dibuat sementara. Pengembangan program pembiasaan perilaku baik di rumah dan orang tua wajib melaporkan tugas yang diberikan setiap harinya dengan video atau foto (Contesa, 2020).

Media yang digunakan sekolah pada proses pembelajaran daring 
berbeda-beda, tergantung dari pihak sekolah mana yang dianggap bagus dan cocok untuk digunakan sebagai media pembelajaran, ada beberapa sekolah yang menggunakan media Zoom untuk melakukan pembelajaran daring bersama siswanya, ada juga yang menggunakan media Google Meet untuk melakukan pembelajaran daring bersama siswa dan untuk pengumpulan tugas biasanya menggunakan media Google Form.

Pembelajaran secara daring tidak jauh berbeda dengan pembelajaran secara luring, pemberian tugas tetap ada namun berbeda pada saat di kelas, yang beban tugasnya dikurangi sedikit. Siswa tetap mengerjakan tugas yang diberikan oleh gurunya untuk pengambilan nilai. Pemberian tugas tidak mesti setiap hari, dilihat juga dari situasi dan kondisi pada saat itu apakah memungkinkan untuk diberikan tugas yang sesuai dengan materi atau tidak memungkinkan diberikan tugas. Siswa harus memperhatikan guru pada saat memberikan materi, agar siswa bisa paham dan mengerti dengan materi yang diterima pada saat pembelajaran daring.

Pembelajaran daring yang diterapkan lebih cenderung pada bentuk penugasan via aplikasi. Siswa diberikan tugas-tugas untuk diselesaikan kemudian dikoreksi oleh guru sebagai bentuk penilaian dan diberikan komentar sebagai bentuk evaluasi (Syarifudin, 2020).

Dalam proses pembelajaran daring siswa didampingi oleh gurunya. Ketika mendapatkan kesulitan dari materi yang diberikan oleh guru, siswa bisa melakukan browsing materi yang didapat untuk membantunya pada saat proses pembelajaran jika itu diijinkan oleh gurunya.

Pembelajaran daring atau pembelajaran jarak jauh dilakukan secara online oleh guru dan siswa untuk melakukan pembelajaran seperti di kelas. Pembelajaran ini dinilai kurang efektif karena masih ada beberapa siswa/orang tua siswa tidak memiliki ponsel dan terkendala oleh jaringan internet.

Dalam pembelajaran jarak jauh atau pembelajaran daring sampai saat ini, hanya efektif dalam mengerjakan penugasan yang diberikan oleh gurunya. Tapi, dalam hal pembelajaran untuk memahami konsep sampai refleksi tidak berjalan dengan baik (Ashari, 2020).

Pemberian materi pada saat pembelajaran daring berupa Power Point (PPT) berisikan materi yang sesuai dengan pembelajaran daring berlangsung. Selama pembelajaran daring guru tidak terlalu menuntut pemberian tugas kepada siswa hanya saja diberikan latihan-latihan soal yang sesuai dengan materi berlangsung.

Media yang digunakan pada saat pembelajaran daring dan pengumpulan tugas yaitu Whatsapp, sudah terlaksana dengan baik, tetapi kadang kala terkendala dengan sinyal internet siswa.

Minat belajar adalah salah satu faktor yang sangat penting untuk keberhasilan belajar yang dimiliki siswa, minat muncul dari dalam diri siswa itu sendiri. Faktor dari luar minat belajar yaitu bagaimana cara guru tersebut mengajar. Peran guru sangat penting untuk menumbuhkan minat belajar siswa salah satu dengan cara mengajar dengan metode yang menyenangkan siswa, termasuk memberikan motivasi yang membangun (Riamin, 2016).

Cara untuk menumbuhkan minat belajar siswa yaitu memberikan video edukasi yang menarik agar siswa bisa tertarik pada pembelajaran yang sedang berlangsung, dan dalam pembelajaran daring juga guru menyampaikan motivasi belajar dan semangat untuk belajar meskipun menyapa hanya secara virtual.

Pada saat pembelajaran daring guru memberikan motivasi kepada siswa agar siswa tidak merasa jenuh, tidak lemas, dan minat belajar siswa tetap ada.

Pi: Mathematics Education Journal 
Guru juga tetap memperhatikan siswa sebagaimana mestinya seperti di kelas. Jika siswa tidak mengetahui atau memahami tentang materi tersebut guru membantu siswa dalam mengalami kesulitan sehingga siswa paham dengan materi yang telah diberikan oleh guru.

Cara meningkatkan minat belajar kepada siswa sebagai berikut, minat belajar dapat ditingkatkan dengan tujuh langkah. Pertama, dengan mengartikulasikan tujuan pembelajaran atau menyusun tujuan pembelajaran yang sesuai dengan keadaan siswa. Kedua, dengan membuat relevansi antara materi pembelajaran dengan kehidupan akademik siswa dan yang mudah dipahami oleh siswa. Ketiga, dengan menunjukkan relevansi materi ajar dengan kehidupan profesional siswa, yang diketahui oleh siswa. Keempat, dengan menyoroti berbagai penerapan pengetahuan dan keterampilan di dunia nyata yang diketahui oleh siswa. Kelima, guru dapat menghubungkan pembelajaran dengan minat pribadi siswa. Keenam, memberikan kebebasan bagi siswa untuk membuat keputusan atau pilihan dan tidak memberatkan siswa. Ketujuh, guru dapat menunjukkan gairah dan sikap antusias untuk meningkatkan minat belajar siswa agar siswa tidak mudah bosan pada waktu pembelajaran (Ricardo \& Meilani, 2017).

Siswa yang memiliki minat terhadap suatu pelajaran akan mempelajarinya dengan sungguhsungguh karena adanya daya tarik baginya, sehingga dapat didefinisikan bahwa minat belajar merupakan suatu keadaan yang menunjukkan kecenderungan perhatian atau tertarik terhadap suatu pelajaran tertentu.

Pembelajaran daring ini berpengaruh terhadap minat belajar siswa dikarenakan pembelajaran yang berbeda dari pembelajaran kelas. Minat belajar siswa bisa turun dikarenakan video yang diberikan kurang menarik. Pada pembelajaran di kelas, kalau minat belajar siswa sudah turun dan tidak semangat lagi, biasanya guru memberikan permainan atau bernyanyi bersama.

Tabel 3.1 Respon Minat belajar Siswa Terhadap Pembelajaran daring

\begin{tabular}{ccc}
\hline Variabel & Persentase & Keterangan \\
\hline $\begin{array}{c}\text { Sistem } \\
\text { Pembelajaran } \\
\text { online (daring ) }\end{array}$ & $56.2 \%$ & Sedang \\
\hline Sumber : Data diolah oleh penulis $(2020)$
\end{tabular}

Sumber : Data diolah oleh penulis (2020)

Berdasarkan data di atas didapatkan bahwa hasil analisis pembelajaran matematika dengan menggunakan sistem pembelajaran daring di Kelas VII MTs Yasrib Batu-batu termasuk dalam kategori setuju. Pembelajaran daring menunjukkan hal yang positif bagi siswa Kelas VII MTs Yasrib Batu-batu. Hal tersebut ditandai dengan sebagian besar siswa memberi tanggapan yang positif atau tertarik menggunakan sistem pembelajaran daring. Berdasarkan tingkat persentase hasil ketertarikan siswa terhadap pembelajaran matematika Kelas VII MTs Yasrib Batu-batu melalui media pembelajaran dengan sistem pembelajaran online (daring) diperoleh persentase sebesar 56,2\% artinya ada ketertarikan sebagian besar siswa terhadap pembelajaran dengan sistem daring dimana pembelajaran ini peneliti menggunakan whatsApp group. Pada pembelajaran ini siswa lebih memilih pembelajaran daring dengan whatsapp group karena dianggap lebih hemat kuota dibandingakn dengan aplikasi lain. Berdasarkan hasil di atas dapat disimpulkan bahwa pembelajaran berbantuan media pembelajaran dengan sistem pembelajaran online (daring) pada mata pelajaran matematika di Kelas VII MTs Yasrib Batu-batu dapat meningkatkan minat belajar siswa ketika situasi pandemi saat ini.

Pi: Mathematics Education Journal 


\section{Kesimpulan}

Pandemi COVID-19 merupakan musibah yang memilukan bagi seluruh penduduk bumi. Seluruh kehidupan manusia di bumi terganggu, tanpa kecuali pendidikan. Banyak negara memutuskan menutup sekolah, perguruan tinggi maupun universitas, termasuk negara Indonesia.

Minat belajar adalah salah satu faktor yang sangat penting untuk keberhasilan belajar yang dimiliki siswa, minat muncul dari dalam diri siswa itu sendiri

Berdasarkan data yang didapatkan bahwa hasil analisis pembelajaran matematika dengan menggunakan sistem pembelajaran daring di Kelas VII MTs Yasrib Batu-batu termasuk dalam kategori setuju. Pembelajaran daring menunjukkan hal yang positif bagi siswa Kelas VII MTs Yasrib Batu-batu. Hal tersebut ditandai dengan sebagian besar siswa memberi tanggapan yang positif atau tertarik menggunakan sistem pembelajaran daring. Berdasarkan tingkat persentase hasil ketertarikan siswa terhadap pembelajaran matematika Kelas VII MTs Yasrib Batu-batu melalui media pembelajaran dengan sistem pembelajaran online (daring) diperoleh persentase sebesar $56,2 \%$ artinya ada ketertarikan sebagian besar siswa terhadap pembelajaran dengan sistem daring dimana pembelajaran ini peneliti menggunakan whatsApp group. Pada pembelajaran ini siswa lebih memilih pembelajaran daring dengan whatsapp group karena dianggap lebih hemat kuota dibandingkan dengan aplikasi lain. Berdasarkan hasil di atas dapat disimpulkan bahwa pembelajaran berbantuan media pembelajaran dengan sistem pembelajaran online (daring) pada mata pelajaran matematika di Kelas VII MTs Yasrib Batu-batu dapat meningkatkan minat belajar siswa ketika situasi pandemi saat ini.

\section{Ucapan Terima Kasih}

Selesainya pembuatan artikel ini tidak lepas dari motivasi serta bantuan yang sangat berarti oleh semua pihak yang mempunyai andil di dalamnya. Oleh karena itu pada kesempatan ini penulis mengucapkan banyak terima kasih yang tak terhingga kepada:

1. Ayah dan Ibu serta keluarga tercinta atas segala cinta dan kasinhnya yang senantiasa mendoakan dan memberikan dorongan spiritual kepada penulis.

2. Bapak/Ibu dosen pembimbing yang telah memberikan masukan dan dukungan dalam membuat artikel.

3. Responden yang menjadi partisipan dalam artikel ini.

4. Teman-teman yang telah bekerja sama dan memberikan bantuan selama pembuatan artikel.

\section{Referensi}

Adhi, G. (2020). Minat Belajar. https://www.tripven.com/minat-belajar/

Andriani, R \& Rasto, R. (2019). Motivasi belajar sebagai determinan hasil belajar siswa. Jurnal Pendidikan Manajemen Perkantoran.

https://ejournal.upi.edu/index.php/jpman per/article/view/14958

Ashari, M. (2020). Proses Pembejalaran Daring di Tengah Antisipasi Penyebaran Virus Corona Dinilai Belum Maksimal.https://www.pikiranrakyat.com/pendidikan/pr01353818/proses-pembejalaran-daringdi-tengah-antisipasi-penyebaran-

Aulia, S. (2020). Pembelajaran Daring Pada Masa

Pandemi.https://yoursay.suara.com/news /2020/07/20/175556/pembelajarandaring-pada-masa-pandemi

Contesa, D. (2020). Hubungan Orang Tua dengan Minat Belajar Siswa pada Masa

Pi: Mathematics Education Journal 
Covid-

19.https://mahasiswaindonesia.id/hubung an-orang-tua-dengan-minat-belajarsiswa-pada-masa-covid-19/

Fadli, $\mathrm{R}$. (2020) Coronavirus.https://www.halodoc.com/k esehatan/coronavirus

Isbaniah, F dkk. (2020). Pedoman Kesiapsiagaan Menghadapi Coronavirus Disesase.

https://www.kemkes.go.id/resources/dow nload/info-terkini/COVID-

19\%20dokumen\%20resmi/2\%20Pedoma n\%20Pencegahan\%20dan\%20Pengendal ian\%20Coronavirus\%20Disease\%20(CO VID-19).pdf

Meidawati, dan S., \& Veteran Bangun Nusantara Sukoharjo, U. (2019). Pengaruh Daring Learning terhadap Hasil Belajar IPA Siswa Sekolah Dasar Abstrak.Seminar Nasional Sains \& Entrepreneurship, 1(1), 1-5. https://scholar.google.co.id/scholar?hl=id \&as sdt $=0 \% 2 \mathrm{C} 5 \mathrm{\& q}=$ Pengaruh $+\mathrm{D}+\mathrm{a}+\mathrm{ri}+$ $n+g+L+e+a+r+n+i+n+g+$ terhadapHasilB elajarIPASiswaSekolahDasar\&btnG=

Mulyana, A. (2020) Pengertian Minat dan Minat Belajar Siswa.https://ainamulyana.blogspot.com/ 2012/02/minat-belajar.html

Purwanto, A dkk.( 2020). Studi Eksploratif Dampak Pandemi COVID-19 Terhadap Proses Pembelajaran Online di Sekolah Dasar. $\quad$ https://ummaspul.ejournal.id/Edupsycouns/article/view/397

Riamin. (2016). Menumbuhkan Minat Belajar Siswa dalam Pembelajaran.https://www.kompasiana.c om/riamin/570ec6323697738d1a3e38b6/ menumbuhkan-minat-belajar-siswadalam-pembelajaran

Ricardo, R., \& Meilani, R. I. (2017). Impak minat dan motivasi belajar terhadap hasil belajar siswa. Jurnal Pendidikan Manajemen Perkantoran (JPManper), 2(2), 188-201. https://ejournal.upi.edu/index.php/jpman per/article/view/8108

Sobron, A. N., Bayu, B., Rani, R., \& Meidawati, M. (2019). Pengaruh Daring Learning terhadap Hasil Belajar IPA Siswa Sekolah Dasar.In Seminar Nasional Sains \&

Pi: Mathematics Education Journal

http://ejournal.unikama.ac.id/index.php/pmej
Entrepreneurship (Vol. $\quad 1, \quad$ No. 1).https://scholar.google.co.id/scholar?hl $=\mathrm{id} \& \mathrm{as} \_\mathrm{sdt}=0 \% 2 \mathrm{C} 5 \& \mathrm{q}=$ Pengaruh $+\mathrm{D}+\mathrm{a}$ $+\mathrm{ri}+\mathrm{n}+\mathrm{g}+\mathrm{L}+\mathrm{e}+\mathrm{a}+\mathrm{r}+\mathrm{n}+\mathrm{i}+\mathrm{n}+\mathrm{g}+$ terhadapHa $\underline{\text { silBelajarIPASiswaSekolahDasar\&btnG }}$ $=$

Sugianto, O. (2020). Penelitian Kualitatif, Manfaat dan Alasan Penggunaan. https://binus.ac.id/bandung/2020/04/pene litian-kualitatif-manfaat-dan-alasanpenggunaan/

Syah, R. H. (2020). Dampak Covid-19 pada Pendidikan di Indonesia: Sekolah, Keterampilan, dan Proses Pembelajaran. http://journal.uinjkt.ac.id/index.php/sala $\mathrm{m} /$ article/view/15314

Syarifudin, A. S. (2020). Impelementasi Pembelajaran Daring Untuk Meningkatkan Mutu Pendidikan Sebagai Dampak Diterapkannya Social Distancing.Jurnal Pendidikan Bahasa Dan Sastra Indonesia Metalingua, 5(1), 31-34.

https://doi.org/10.21107/metalingua.v5i1 .7072

Tiarasari, R. (2020). Update Covid-19 Global Rabu, 4 November 2020 Malam .https://palu.tribunnews.com/2020/11/04/ update-covid-19-global-rabu-4november-2020-malam-ada-1216173kasus-kematian-di-seluruh-dunia.

Wahyono, P., \& Husamah, H. (2020).Jurnal pendidikan profesi guru. 